\title{
KEDUDUKAN ANAK ANGKAT DALAM HUKUM WARIS ISLAM DAN HINDU
}

\author{
Zakiyatul Ulya
}

\author{
Fakultas Syariah dan Hukum UIN Sunan Ampel Surabaya. \\ Email: ulyaelzakiya@gmail.com
}

\begin{abstract}
Both of Islam and Hindu have regulated in detail the issues of inheritance. If the two are compared, it can be seen that there is a difference in positioning adopted child, where in Hindu law is used as the cause of inheritance whereas in Islamic law it is not. Thus, it can be seen that the adopted child does not belong to the heirs in Islamic law, so the inheritance rights remain to his biological family, not his adopted family. However, they can get a share of the property of their adopted parents by the way of a testament not more than $1 / 3$ of a part, even in this case, article 209 paragraph 2 of KHI states that against a adopted child who does not receive a will is given a maximum of $1 / 3$ of the inheritance of his adopted parents. Unlike the Islamic law, Hindu law classifies adopted sons including in heirs whose inheritance rights are transferred to their adopted families and are equal to those of legitimated children who inherit in the first place with the possibility to obtain all parts if no children are equal.
\end{abstract}

Keywords: Adopted child, Islamic inheritance law, Hindu inheritance law.

Abstrak: Baik hukum Islam maupun Hindu telah mengatur secara rinci berbagai persoalan mengenai kewarisan. Jika keduanya dibandingkan, dapat diketahui bahwa terdapat perbedaan dalam memposisikan pengangkatan angkat, yang mana dalam hukum Hindu dijadikan sebagai penyebab mewarisi sedangkan dalam hukum Islam tidak. Dengan demikian, dapat diketahui bahwa anak angkat tidak termasuk golongan ahli waris dalam Hukum Islam, sehingga hak mewarisinya tetap ke keluarga kandungnya, bukan keluarga angkatnya. Akan tetapi, bisa mendapat bagian dari harta orang tua angkatnya dengan jalan wasiat yang tidak lebih dari $1 / 3$ bagian, bahkan dalam hal ini, pasal 209 ayat $2 \mathrm{KHI}$ menyatakan bahwa terhadap anak angkat yang tidak menerima wasiat diberi wasiat wajibah sebanyak-banyaknya $1 / 3$ dari harta warisan orang tua angkatnya. Berbeda halnya dengan Hukum Islam, Hukum Hindu menggolongkan anak angkat (laki-laki) termasuk ke dalam ahli waris yang hak mewarisinya berpindah ke keluarga angkatnya dan kedudukannya sama dengan anak sah yang mewarisi pada urutan pertama dengan kemungkinan bagiannya adalah seluruh bagian jika tidak ada anak sama sekali atau sama dengan bagian anak sah, dalam arti mewaris bersama.

Kata kunci: Anak angkat, Hukum Waris Islam, Hukum Waris Hindu.

AL-HUKAMA

The Indonesian Journal of Islamic Family Law

Volume 07, Nomor 02, Desember 2017; ISSN:2089-7480 


\section{Pendahuluan}

Pengangkatan anak atau biasa dikenal dengan istilah adopsi merupakan sebuah fenomena yang sering terjadi dalam masyarakat tanpa perduli lapisan sosialnya. Pengangkatan anak sendiri dapat diartikan sebagai suatu tindakan mengambil anak orang lain untuk dipelihara dan diperlakukan sebagai anak kandungnya sendiri berdasarkan ketentuan-ketentuan yang disepakati bersama dan sah menurut hukum yang berlaku di masyarakat yang bersangkutan. Pengangkatan anak terjadi baik dari kalangan keluarga maupun bukan. Motifnya pun beragam, antara lain:

1. Alasan kemanusiaan, yaitu rasa belas kasihan terhadap anak terlantar atau anak yang orang tuanya tidak mampu memeliharanya.

2. Keinginan seseorang yang tidak memiliki anak agar ada yang menjaga dan memeliharanya di kemudian hari.

3. Menyambung keturunan dan mendapatkan regenerasi bagi yang tidak mempunyai anak kandung.

4. Pemancing bagi yang tidak mempunyai anak untuk dapat mempunyai anak kandung.

5. Mencarikan teman untuk anaknya yang sudah ada.

6. Mendapatkan atau menambah tenaga kerja dalam keluarga.

7. Mempertahankan ikatan perkawinan atau kebahagiaan keluarga.

Adapun dari pihak orang tua kandung, penyerahan anak kepada orang tua angkat tidak lepas juga dari berangam motif, di antaranya:

1. Merasa tidak memiliki kemampuan untuk membesarkan anak.

2. Melihat ada kesempatan untuk meringankan bebannya.

3. Memiliki banyak anak.

4. Rasa kasihan kepada keluarga yang tidak memiliki anak.

5. Adanya imbalan dari orang tua angkatnya.

6. Ingin anaknya mendapatkan penghidupan/ masa depan yang lebih baik.

7. Tidak menghendaki anak kandungnya karena berasal dari hubungan yang tidak sah atau yang tidak diinginkan.

Praktik pengangkatan anak sendiri rentan sekali memunculkan permasalahan dalam keluarga, baik keluarga kandung maupun keluarga angkat dan bagi anak angkat itu sendiri. 
Masalah terbesar akan terjadi manakala anak yang diadopsi telah dewasa, apalagi jika anak angkatnya perempuan, yang akan memunculkan pertanyaan siapa yang berhak menikahkan. Selain itu, masalah yang besar juga akan terjadi manakala anak angkat atau orang tua, baik orang tua kandung maupun angkatnya meninggal, yang akan memunculkan pertanyaan siapa yang berhak mewarisinya. Kedua masalah tersebut tidak jarang menemukan jalan buntu, dalam arti tidak dapat diselesaikan, bahkan tidak jarang masalah yang kedua menimbulkan perselisihan yang berkepanjangan karena berhubungan dengan harta sehingga tak jarang berujung ke ranah hukum.

Peristiwa kematian akan menimbulkan akibat hukum kepada orang lain, terutama pada pihak keluarganya dan pihak-pihak tertentu yang mempunyai hubungan dengan orang tersebut semasa hidupnya yang semuanya diatur dalam hukum kewarisan. Adapun hukum di Indonesia sendiri merupakan campuran dari sistem hukum Eropa, hukum agama serta hukum adat, yang mana semuanya mempunyai aturan masing-masing mengenai pewarisan termasuk di dalamnya mengenai kedudukan anak angkat dalam pewarisan. Berbagai penelitian pun telah dilakukan oleh banyak akademisi terkait hal tersebut, terutama yang mencoba membandingkan kedudukan anak angkat itu dalam hukum negara, agama dan adat. Akan tetapi, dalam hal ini, hukum Islam lah yang selalu jadi rujukan.

Oleh karena itu, menjadi penting jika kedudukan anak angkat yang ada dalam hukum Islam ini dibandingkan dengan aturan hukum agama lain, yang dalam hal ini dipilih agama Hindu karena kemudahan dalam mendapatkan sumber hukumnya. Diketahui bahwa baik hukum Islam maupun hukum Hindu telah mengatur secara rinci berbagai persoalan mengenai kewarisan, yang diantaranya meliputi sebab-sebab mendapatkan, penggolongan ahli waris dan bagiannya masing-masing beserta tata cara pembagian harta warisan. Lantas bagaimana kedudukan anak angkat dalam hukum kewarisan Islam dan Hindu akan dibandingkan lebih lanjut dalam artikel ini. 


\section{Sistem Pewarisan dalam Islam}

Syariah Islam telah menetapkan aturan waris dengan sangat teratur dan adil yang di dalamnya telah ditetapkan hak kepemilikan harta bagi setiap manusia, baik laki-laki maupun perempuan dan juga hak pemindahan kepemilikan seseorang sesudah meninggal dunia kepada ahli warisnya dari seluruh kerabat dan nasabnya, 1 sebagaimana firman Allah Swt. dalam surah al-Nisa ayat 7 yang artinya:

Bagi laki-laki ada hak bagian dari harta peninggalan ibu-bapake dan karib kerabat dan bagi perempuan ada bak bagian (pula) dari harta peninggalan ibu-bapak dan kerabatnya, baik sedikit maupun banyak. menurut bagian yang telab ditentukan.

Selain itu, Nabi Muhammad saw. juga pernah bersabda dalam sebuah hadis yang artinya:

Berikanlah faraid (bagian-bagian yang ditentukan) itu kepada yang berhake dan selebibnya berikanlah untuk laki-laki dan keturunanmu laki-laki yang terdekat." (H.R Bukhari) 2

Pewarisan harta tersebut tidak lain meliputi seluruh harta yang dimiliki, baik yang berkaitan dengan harta kekayaan maupun hak-hak lain yang tergantung kepadanya, misalnya utang piutang dan hak ganti rugi.3

Ada empat sebab yang menjadikan seseorang mendapatkan warisan, yaitu:

1. Kerabat hakiki, yaitu adanya ikatan nasab/kekerabatan, seperti kedua orang tua, anak, saudara, paman dan seterusnya.4 Hal ini sesuai firman Allah dalam surat al'Anfal ayat 75,5 yang berbunyi:

1 M. Ali ash-Shabuni, Pembagian Waris Menurut Islam, terj. A.M. Basalamah (Jakarta: Gema Insani Press, 1995), 32.

2 Muhammad ibn Isma'il ibn 'Abdullah al-Ja'fiy, Sabih al-Bukhari (Beirut: Dar alFikr, 1987), 6.

3 Abdur Rahman I. Doi, Syariah II; Hudud dan Kewarisan, terj. Zaimuddin, et al. (Jakarta: PT Raja Grafindo Persada, 1996), 98.

4 M. Ali ash-Shabuni, Pembagian Waris Menurut Islam, 39.

5 Sayyid Sabiq, Fikih Sunnah, 14, terj. Mudzakir (Bandung: PT Alma'arif, 1987), 258. 
Zakiyatul Ulya: Kedudukan Anak Angkat dalam Hukum...

...... Orang-orang yang mempunyai bubungan kerabat itu sebagiannya lebih berhak terhadap sesamanya (daripada yang bukan kerabat) menurut Kitab Allah......

Islam menghendaki agar harta peninggalan tidak hanya bertumpuk pada salah satu anggota keluarga, tetapi dapat dinikmati oleh seluruh keluarga sesuai bagian masing-masing yang telah ditetapkan syari'at, agar tidak terjadi perselisihan dikemudian hari. Oleh karena itu, agama Islam memberikan hak mewarisi kepada sejumlah kerabat dengan memperhatikan derajat kekerabatan mereka. Kerabat yang derajatnya lebih kuat dan lebih dekat niscaya diberi warisan lebih banyak daripada kerabat yang derajatnya lebih rendah dan lebih jauh.7

2. Penikahan, yaitu terjadinya akad nikah secara syar'i antara seorang laki-laki dan perempuan sekalipun belum atau tidak terjadi hubungan intim antar keduanya.s Adapun yang menjadi dasar adanya perkawinan menjadi sebab pewarisan adalah surat al-Nisa' ayat 12,9 yang artinya:

Dan bagimu (suami-suami) adalah seperdua dari barta yang ditinggalkan oleh isteri-isterimu, jika mereka tidak mempunyai anak. Jika istteri-isterimu itu mempunyai anak, maka kamu mendapat seperempat dari harta yang ditinggalkannya sesudah dipenubi wasiat yang mereka buat atau (dan) sesudah dibayar hutangnya. Para isteri memperoleh seperempat harta yang kamu tinggalkan jika kamu tidake mempunyai anak. Jika kamu mempunyai anak, maka para isteri memperoleh seperdelapan dari harta yang kamu tinggalkan sesudah dipenubi wasiat yang kamu buat atau (dan) sesudab dibayar butangbutangmu...10

6 Departemen Agama RI, Al-Quran dan Terjemahnya (Bandung: Diponegoro, 2010), 186.

7 Fatchur Rahman, Ilmu Waris (Bandung: Al-Ma'arif, 1974), 121.

8 M. Ali ash-Shabuni, Pembagian Waris Menurut Islam, 39.

9 Sayyid Sabiq, Fikib Sunnah 14, 259.

10 Departeman Agama, Al-Quran dan Terjemahnya, 79. 
Pernikahan yang menjadi sebab timbulnya hubungan kewarisan antara suami dengan isteri didasarkan pada dua syarat, yaitu sebagai berikut:

a. Pernikahan itu sah menurut syariat Islam artinya telah memenuhi rukun dan syaratny serta terlepas dari semua halangan.

b. Pernikahannya masih utuh, dalam arti suami isteri masih terikat tali pernikahan saat salah satu pihak meninggal dunia.11

3. Al-Wala', yaitu kekerabatan secara hukum yang dibentuk oleh syari' karena memerdekakan budak (wala' al-'itqi).12 Hal ini sebagaimana sabda Rasulullah 13 yang artinya:

Telah menceritakan kepada kami Isma'il ibn 'Abdullah, beliau berkata bahwa Malik, telah menceritakan padaku (Isma'il) dari Nafi' dari Ibnu 'Umar babwa Nabi SAW telab bersabda: "Sesunggubnya waris wala' itu banya bagi orang yang memerdekakannya. H.R. Bukhari14

Orang yang memerdekakan bisa mewarisi harta orang yang memerdekakan, namun, tidak sebaliknya. Artinya, orang yang dimerdekakan tidak bisa mewarisi harta orang yang memerdekakan.

4. Representasi Islam

Syafi'iyah dan Malikiyyah menambahkan sebab yang keempat yaitu representasi Islam. Peninggalan orang muslim yang tidak memiliki ahli waris dengan ketiga sebab di atas diberikan kepada Baitul Mal sebagai warisan kepada orangorang Muslim dalam bentuk 'asabah, karena Rasulullah saw. pernah bersabda yang artinya:

Telah menceritakan kepada kami Yabya ibn Durusta, telab menceritakan kepada kami Hammad ibn Yazid dari Budail ibn

11 Moh. Muhibbin dan Abdul Wahid. Hukum Kewarisan Islam; Sebagai Pembaharuan Hukum Positif di Indonesia (Jakarta: Sinar Grafika, 2009), 73-74.

12 M. Ali ash-Shabuni, Pembagian Waris Menurut Islam, 39.

13 Ahmad 'Abd al-Jawad, Usul; Ilm al-Mawaris (Beirut: Dar al-Ji, 1986), 3.

14 Imam Abi Abdillah Muhammad ibn Isma'il ibn Ibrahim ibn al-Mughirah ibn Bardazabah al-Bukhari al-Ja'fiyyi, Sabih al-Bukhari, juz VIII (Beirut: Dar al-Fikr, 2000), 11. 
Maisarah dari 'Ali ibn Abi Talhah dari Rashid ibn Sa'd dari Abi 'Amir al-Hanzaniyyi dari al-Miqdam al-Shamiyyi berkata: Rasulullah $S A W$ bersabda: Aku adalah abli waris orang yang tidak mempunyai abli waris. Aku menanggung denda atas jinayatnya dan aku mewariskannya. Paman (dari pibak ibu) adalah pewaris orang yang tidak memiliki abli waris, ia menanggung diyatnya dan mewarisinya. H.R. Ibnu Majaht5

Nabi Muhammad tidak mewariskan untuk dirinya sama sekali, tetapi mengelolanya untuk kemaslahatan umat.16

Golongan ahli waris yang telah disepakati hak warisnya terdiri atas 15 orang laki-laki dan 10 orang perempuan, dengan rincian sebagai berikut:

1. Kelompok ahli waris laki-laki terdiri dari anak laki-laki, cucu laki-laki dari garis keturunan laki-laki dan seterusnya ke bawah, bapak, kakek shahih dan seterusnya ke atas, saudara laki-laki sekandung, saudara laki-laki sebapak, saudara laki-laki seibu, anak laki-laki saudara laki-laki sekandung, anak laki-laki saudara laki-laki sebapak, paman sekandung, paman sebapak, anak lakilaki paman sekandung, anak laki-laki paman sebapak, suami dan orang laki-laki yang memerdekakan budak.

2. Kelompok ahli waris perempuan terdiri dari anak perempuan, cucu perempuan dari garis keturunan laki-laki dan seterusnya ke bawah ibu, nenek dari pihak bapak dan seterusnya ke atas, nenek dari pihak ibu dan seterusnya ke atas, saudara perempuan sekandung, saudara perempuan sebapak, saudara perempuan seibu, isteri dan orang perempuan yang memerdekakan budak.17

Dari kedua puluh lima ahli waris tersebut dibedakan menjadi tiga kelompok, yaitu:

15 Abu 'Abdillah Muhammad ibn Yazid al-Quzwaini, Sunan Ibn Majah, juz VIII (t.tp.: t.p., t.t.), 185 .

16 Wahbah al-Zuhaili, Fiqib Islam wa Adillatubu, 10, terj. Abdul Hayyie al-Kattani, et al. (Jakarta: Gema Insani, 2011), 348-349.

$17 \mathrm{Ah}\} \mathrm{mad}$ 'Abd al-Jawad, Usul; Ilm al-Mawaris, 4. 
1. Ashab al-Furud merupakan para ahli waris yang mempunyai bagian tertentu $(2 / 3,1 / 3,1 / 6,1 / 2,1 / 4$ dan $1 / 8)$ yang telah ditetapkan oleh syara', 18 dengan rincian sebagai berikut:

a. Anak perempuan mendapat bagian $1 / 2$ jika sendiri serta tidak bersama anak laki-laki dan $2 / 3$ jika dua orang atau lebih serta tidak bersama anak laki-laki.

b. Cucu perempuan dari garis keturunan laki-laki seterusnya ke bawah mendapat bagian $1 / 2$ jika sendiri serta tidak bersama cucu laki-laki, 2/3 jika dua orang atau lebih serta tidak bersama cucu laki-laki dan $1 / 6$ jika ada anak perempuan seorang saja.

c. Ibu mendapat bagian 1/6 jika bersama dengan anak atau cucu dari pewaris atau bersama dua orang saudara atau lebih, $1 / 3$ jika tidak bersama dengan anak atau cucu, tetapi hanya bersama bapak dan $1 / 3$ dari sisa jika tidak bersama anak atau cucu, tetapi bersama suami atau isteri.

d. Bapak mendapat bagian 1/6 jika bersama dengan anak atau cucu laki-laki dan 1/6 kemudian mengambil sisa harta jika bersama dengan anak atau cucu perempuan.

e. Kakek dan seterusnya ke atas mendapat bagian yang sama dengan bapak karena berkedudukan sebagai pengganti bapak ketika bapak sudah tidak ada.

f. Nenek mendapat bagian $1 / 6$, baik seorang atau lebih.

g. Saudara perempuan sekandung mendapat bagian $1 / 2$ jika hanya seorang serta tidak bersama saudara laki-laki dan $2 / 3$ jika ada dua orang atau lebih serta tidak bersama saudara laki-laki.

h. Saudara perempuan sebapak mendapat bagian $1 / 2$ jika hanya seorang serta tidak ada saudara laki-laki sebapak, $2 / 3$ jika ada dua orang atau lebih serta tidak ada saudara laki-laki sebapak dan $1 / 6$ jika bersama seorang saudara perempuan kandung.

i. Suami mendapat bagian $1 / 2$ jika tidak ada anak atau cucu dan $1 / 4$ jika ada anak atau cucu.19

18 Suparman Usman dan Yusuf Somawinata, Fiqih Mawaris; Hukum Kewarisan Islam (Jakarta: Gaya Media Pratama, 2002), 66.

19 Amir Syarifuddin, Hukum Kewarisan Islam (Jakarta: Kencana, 2004), 228-229. 
j. Isteri mendapat bagian $1 / 4$ jika tidak bersama anak atau cucu dari pewaris dan $1 / 8$ jika bersama dengan anak atau cucu pewaris.

k. Saudara laki-laki seibu mendapat bagian $1 / 6$ jika hanya seorang dan $1 / 3$ jika lebih dari seorang.

1. Saudara perempuan seibu mendapat bagian $1 / 6$ jika hanya seorang dan $1 / 3$ untuk dua orang atau lebih. 20

2. 'Asabah merupakan ahli waris yang tidak mempunyai bagian tertentu, tetapi menerima sisa pembagian setelah diambil oleh ahli waris ashab al-furud.21 Secara umum, ashabah terbagi menjadi dua, yaitu:

a. 'Asabah nasabiyyah, yaitu 'asabah yang disebabkan adanya hubungan darah dengan pewaris. 'Asabah nasabiyyah ini terbagi menjadi tiga, yaitu:

1) 'Asabah binafsib, yaitu 'asabah karena kedudukannya sendiri yang terdiri dari seluruh ahli waris laki-laki kecuali suami dan saudara laki-laki seibu.

2) 'Asabah bi al-ghair, yaitu 'asabah yang disebabkan oleh orang lain, misalnya anak perempuan menerima bagian 'asabah karena bersama anak laki-laki.

3) 'Asabah ma'a al-ghair, yaitu 'asabah karena mewarisi bersama orang lain, misalnya saudara perempuan seibu sebapak/sebapak saja menerima bagian 'asabab jika bersama dengan anak perempuan.

b. 'Asabah sababiyyah, yaitu menjadi ashabah karena adanya suatu sebab yang dalam hal ini adalah karena ada perbuatan memerdekakan si mayit. dari perbudakan.22

3. Dhawi al-Arham merupakan setiap kerabat yang tidak termasuk ashab al-furud dan juga golongan 'asabah, yang terdiri dari cucu perempuan dari garis keturunan perempuan dan seterusnya ke bawah, cucu laki-laki dari garis keturunan perempuan dan seterusnya ke bawah, anak perempuan saudara laki-laki sekandung dan seterusnya ke bawah, anak perempuan saudara

20 Ibid., 228.

21 Suparman Usman, Fiqih Mawaris, 65.

22 Suhrawardi K. Lubis dan Komis Simanjuntak, Hukum Waris Islam; Lengkap \& Praktik (Jakarta: Sinar Grafika, 2008), 99-101. 
laki-laki sebapak dan seterusnya ke bawah, anak laki-laki saudara perempuan sekandung dan seterusnya ke bawah, anak laki-laki saudara perempuan sebapak dan seterusnya ke bawah serta kakek dari pihak ibu seterusnya ke atas.

berikut:

Adapun aturan pewarisan ketiga golongan ini adalah sebagai

1. Para ahli waris ashab al-furud tersebut harus didahulukan dalam menerima bagian harta warisan daripada golongan 'asabah dan dhawi al-arbam. Oleh karena itu, ada kemungkinan harta warisan dapat habis sama sekali ketika dibagikan kepada para ashab alfurud sesuai dengan bagian masing-masing, ada kemungkinan masih ada sisa. Adapun sisa harta warisan inilah yang kemudian dibagikan kepada ahli waris 'asabah sesuai dengan ketentuan yang ada.

2. Jika tidak ada seorang pun dari ahli waris ashab al-furud, pembagian harta warisan dimulai dari para 'asabab bila mereka ada. Namun, bila tidak ada, dialihkan kepada ahli waris dhawi alarbam. Demikian seterusnya menurut tertib orang-orang yang berhak menerima harta warisan. 23

Akan tetapi, sebelum harta warisan dibagikan ada hal-hal yang harus dilakukan, yaitu:

1. Membiayai penyelenggaraan jenazah mulai dari pengafanan sampai penguburan.

2. Membayar utang si mati.

3. Membayar wasiat si mati dengan syarat tidak boleh melebihi $1 / 3$ harta peninggalan. 24

\section{Sistem Pewarisan dalam Hindu}

Hukum kewarisan dalam Hindu secara definitif dan dari segi pemahaman tidak jauh berbeda dengan hukum kewarisan dalam Islam seperti pendapat yang dikemukakan oleh Ayu Putu Nantri, yaitu suatu proses penerusan dari pewaris kepada ahli waris tentang barang-barang materiil maupun barang-barang immateriil, yang mana hal ini berarti bahwa penerusan ini menyangkut penerusan

23 Fatchur Rahman, Ilmu Waris, 131.

24 Azyumardi Azra, et al., "Waris", Ensiklopedi Islam, vol. 5, ed. Abdul Aziz

Dahlan, et al. (Jakarta: PT Ikrar Mandiri Abadi, 2000), 192. 
hak-hak dan kewajiban-kewajiban.25 Hal ini sebagaimana yang dijelaskan dalam sloka 110 Buku IX kitab Manawa Dharmacastra (Atha Navamo' dhyayah) yang berbunyi:

Setelah kematian seorang ayah dan ibu, saudara karena telah berkumpul dapat membagi-bagi diantara mereka sebanding yang sama dengan kekayaan orang tuanya ibunya karena tidak ada kekuasaan pada mereka atas harta itu selagi hidup orang tuanya".26

Ada lima sebab yang menjadikan seseorang mendapatkan warisan, yaitu:

1. Hubungan kekeluargaan (sedarah/sapinda), yaitu yang dibatasi dibatasi pada tiga tingkat terusan dengan yang meninggal, sesuai dengan sloka 187 Buku IX Kitab Manava Dharmasastra yang artinya:

Hanya kepada keluarga dalam tiga tingkat yang terdekat kepada yang meninggal adalah sapinda yang berhak atas harta warisan dan sesudah itu barulah yang satu keluarga mewaris dana kemudian baru guru spritual atau muridnya.

Selain itu, hubungan kekeluargaan (darah) sebagai sebab seseorang dapat mewaris juga dijelaskan dalam sloka 10-13 Bagian 60 Bab 5 Kitab Artasastra dengan bunyi sebagai berikut:

a. Putera-putera (akan mewarisi) milik pria yang berputera atau berputeri lahir dari perkawinan yang suci. (Sloka 10)

b. Jika semua tidak ada, maka ayahnya (yang mewarisi) jika hidup. (Sloka 11)

c. Jika ayahnya tidak ada, maka saudaranya laki-laki dan anak saudara laki-lakinya (yang mewarisi). (Sloka 12)

25 Hukum Hindu, "Hukum Waris Hindu Berdasarkan Arthasastra", dalam http://hukumhindu.blog.com/2011/06/25/hukum-waris-hindu-berdasarkanarthasastra/, diakses pada 7 Desember 2013.

26 Baghavan Bhrgu, Manava Dharmasastra, terj. G. Pudja dan Tjokorda Rai Sudharta (Surabaya: Paramita, 2004), 464. 
d. Dan anak saudara laki-lakinya, jika tanpa ayah mereka, dapat menerima satu bagian dari ayah, sekalipun jumlahnya banyak, bersama para kakak pria. (Sloka 13)27

2. Pengangkatan status anak perempuan menjadi anak laki-laki (putrika)

Dalam agama Hindu, keturunan laki-laki sangat diharapkan dalam sebuah keluarga, karena orang tuanya dapat mencapai dunia harapan, seperti surga, dunia yang bebas dari penderitaan dan kalau perlu sampai ke alam matahari, yaitu tempat tertinggi.28 Selain itu, anak laki-laki juga dapat menjadi juru selamat yang menyelamatkan pitara 2 dari dunia neraka yang disebut Put. Oleh karena pentingnya kedudukan anak laki-laki tersebut, maka seseorang yang tidak memiliki anak laki-laki boleh menjadikan anak perempuannya sebagai putrika, yaitu anak wanita yang diangkat statusnya menjadi anak laki-laki karena keluarga tidak mempunyai terusan laki-laki, sehingga segala hak dan kewajibannya dipersamakan dengan anak lakilaki, termasuk haknya dalam mewarisi. Hal ini sesuai dengan sloka 127 Buku IX Kitab Manava Dharmasastra yang artinya:

Ia yang tidak mempunyai anak laki-laki dapat menjadikan anaknya yang perempuan menjadi demikian menurut acara penunjukan anak wanita dengan mengatakan kepada suaminya anak laki-laki yang lahir daripadanya akan melakukan upacara penguburan.30

\section{Pengangkatan anak (adopsi)}

Di samping mempunyai anak kandung, dalam hukum Hindu, seseorang dapat pula melakukan adopsi. Setelah terjadi pengangkatan, anak angkat tersebut tidak boleh memakai nama keluarga asalnya dan hak mewarisnya hapus. Meskipun begitu, sejak diadopsi, anak angkat tersebut berhak mewarisi dari

27 Kautilya (Canakya), Artasastra, terj. Made Astana dan Anomdiputro (Surabaya: Paramita, 2003), 236-237.

28 Baghavan Bhrgu, Manava Dharmasastra, 472

29 Roh orang tua yang telah meninggal yang telah disempurnakan karena oleh anaknya telah dilakukan pitra yajna/upacara yang berhubungan dengan kurbankurban bagi roh orang tua yang meninggal.

30 Baghavan Bhrgu, Manava Dharmasastra, 469-471. 
keluarga yang mengangkatnya. Hal ini sesuai dengan sloka 142 Buku IX Kitab Manava Dharmasastra yang artinya:

Anak angkat tidak pernah akan mengambil nama keluarga dan harta warisan dari orang tua yang sebenarnya, tarpana mengikuti nama keluarga dan harta warisan pemberian tarpana kepadanya yang memberikan anaknya untuk diadopsi berakhir sepanjang mengenai anak itu saja.

Kedudukan anak angkat tersebut sama dengan putera sah.31 Hal ini sesuai dengan sloka 15 Bagian 60 Bab 7 Buku 3 Kitab Artasastra yang berbunyi:

Dengan hak sama adalah anak angkat, yang diberi bersama air oleh orang tuanya.32

Oleh karena kedudukannya sama, maka anak angkat tersebut berhak mewaris bersama anak-anak laki-laki kandung orang yang mengadopsinya.33

4. Hubungan guru dan murid

Sebagaimana yang telah disebutkan dalam sloka 187 Buku IX Kitab Manava Dharmasastra bahwa guru atau murid berhak mendapatkan warisan ketika keluarga si meninggal sudah tidak ada. Hal ini juga diperkuat dalam sloka 23 Bagian 60 Bab 6 Kitab Artasastra yang berbunyi:

Kalau tidak ada, guru si ayah atau muridnya (akan menerima dua pertiga).34

5. Berkedudukan sebagai raja/brabmana

Dalam hal pewaris tidak mempunyai turunan sebagai ahli waris, maka brabmana berhak mendapatkan harta warisan. Hal ini dijelaskan dalam sloka 188 Buku IX Kitab Manava Dharmasastra yang artinya:

Tetapi kegagalan dari semua ahli waris, brahmana 35 akan memperoleh bagian dari harta warisan, yang ahli dalam

31 Putera yang diperoleh seseorang dengan isteri yang dikawini dengan baik.

32 Kautilya (Canakya), Artasastra, 243.

33 Baghavan Bhrgu, Manava Dharmasastra, 473-474.

34 Kautilya (Canakya), Artasastra, 241.

35 Brabmana menurut Narayana adalah brabmana yang tinggal sekampung dengan pewaris. 
ketiga Veda, sucizs dan menguasai diri, semikian Undangundang itu tidak dilanggar.

Selain brahmana, raja juga berhak mengambil harta seseorang yang tidak memiliki ahli waris sama sekali (tidak termasuk nafkah isteri dan apa yang diperlukan untuk upacara kematian), kecuali milik seorang brahmana ahli Veda. Hal ini termaktub dalam sloka 23 Bagian 60 Bab 6 Kitab Artasastra yang berbunyi:

Raja akan mengambil dari yang tidak ada pewarisnya, tidak termasuk nafkah isteri dan apa yang diperlukan untuk upacara kematian, kecuali milik seorang brahmana ahli Veda.37

Adapun menurut Kulluka, harta seorang brabmana yang mati punah itu sendiri harus diwariskan kepada brabmana ahli yang terdapat dalam kerajaan itu dan dia diwajibkan untuk melakukan pitrayajna dan Sraddha bagi yang meninggal.38

Kedudukan raja/brabmana sebagai seseorang yang berhak menerima harta warisan milik orang yang tidak memiliki ahli waris juga dijelaskan dalam sloka 10-12 Bagian 60 Bab 5 Kitab Artasastra dengan bunyi:

1) Raja akan mengambil dari yang tidak ada pewarisnya, tidak termasuk nafkah untuk isteri dan apa yang diperlukan untuk upaca kematian, kecuali milik seorang Brabmna ahli Veda. (Sloka 28)

2) Ia akan menghadiahkan itu kepada yang ahli dalam ketiga Veda. (Sloka 29) 39

Kelompok pewarisan dalam agama Hindu secara tersurat disebutkan dalam sloka 185 Buku IX Kitab Manava Dharmasastra yaitu yang artinya:

\footnotetext{
36 Suci menurut Kulluka diartikan dengan selalu berhati-hati dalam segala perbuatan, baik lahir maupun batin.

37 Ibid., 238.

38 Baghavan Bhrgu, Manava Dharmasastra, 485.

39 Kautilya (Canakya), Artasastra, 238.
} 
Bukannya saudara maupun datuk yang mewaris harta orang tua tetapi anak itulah yang mewaris. Hanya seorang ayah pewaris akan menerima bagiannya kalau tidak mempunyai terusan laki-laki.

Dari sloka di atas dapat disimpulkan bahwa kelompok pewarisan terdiri dari kelompok I adalah anak, kelompok II adalah cucu dan cicit, kelompok III adalah janda, kelompok IV adalah saudara dan elompok V adalah orang tua pewaris. Selain kelompok tersebut, terdapat orang-orang yang karena kedudukannya berhak mewarisi seseorang yang tidak memiliki ahli waris, yaitu guru atau murid dan raja atau brabmana.

Adapun lebih luas lagi, menurut sloka 187 Buku IX Kitab Manava Dharmasastra yang telah disebutkan sebelumnya, dalam agama Hindu kelompok pewarisan dapat dibedakan menjadi tiga, yaitu:

1. Sapinda, yaitu keluarga yang mempunyai hubungan darah ke atas tiga tingkat dan kebawah tiga tingkat, sehingga dengan pewaris adalah yang ketujuh.

2. Anantara sapinda, yang berarti terdekat kepada ketiga golongan sapinda tersebut, yaitu keluarga-keluarga lain dalam hubungannya dengan sapinda tersebut.

3. Sakulya, yaitu sekeluarga yang masih tergolong sedarah pula, karena menurut Jimutawahana tiga turunan ke bawah adalah sakulya, sedangkan menurut pendapat penulis lainnya sakulya diartikan sebagai "anggota keluarga dalam satu keluarga" yang dekat hubungannya dan ini tidak perlu sedarah, seperti isteri, keluarga istri dan lain-lain yang sedarah dengan isteri.

Dengan pengertian itu, maka besar kemungkinan bahwa istilah terdekat dengan sapinda, meliputi sapinda dan bukan sapinda, tetapi berhak mewarisi seperti kedudukan sapinda terhadap pewaris. berikut:

Adapun bagian masing-masing ahli waris adalah sebagai

1. Anak laki-laki mendapatkan seluruh bagian harta warisan, jika tidak memiliki saudara atau meskipun terdapat saudara, tetapi anak laki-laki sulung dapat menguasai seluruh harta orang tuanya dalam kedudukannya sebagai pengganti orang tuanya 
yang memiliki tanggung jawab untuk mengasuh saudarasaudaranya. 40

2. Anak laki-laki sulung dan saudara lainnya berbagi sama setelah dikurangi bagian tambahan/dalam posisi 1 1/2 : 1 (dapat diambil terlebih dahulu maupun dibagi secara bersama-sama).

3. Anak laki-laki tertua mendapat bagian satu setengah (1 1/2) dari bagian normal, dimana anak laki-laki lain yang lahir sesudahnya mendapat bagian satu (1).41

4. Anak sulung laki-laki hanya mendapat $1 / 3$ jika dia tidak memiliki sifat jantan atau $1 / 4$ jika dia berkelakuan tidak benar atau melepaskan kewajiban beragama.42 Setelah pembagian dilakukan, maka anak laki-laki tersebut diharuskan memberikan beberapa bagian untuk saudara perempuannya, yang dalam hal ini sebanyak $1 / 4$ bagian.

5. Anak angkat mendapat seluruh bagian jika tidak ada anak sama sekali43 atau sama dengan bagian anak sah, dalam arti mewaris bersama.44

6. Anak perempuan yang diangkat statusnya menjadi anak laki-laki (putrika) mendapat bagian yang sama dengan anak sah atau berbagi sama dengan anak laki-laki yang lahir setelah diadakannya pengangkatan. 45

Adapun aturan pewarisan dalam agama Hindu telah dipaparkan baik dalam kitab Manava Dharmasastra maupun kitab Artasastra, dengan rincian sebagai berikut:

1. Dalam kitab Manava Dharmasastra

Pewarisan sapinda, anantara sapinda dan sakulya tidak secara bersamaan, tetapi bergantian, yaitu dimulai dari golongan sapinda, kemudian anantara sapinda dan sakulya pada urutan terakhir. Adapun jika istilah terdekat dengan sapinda meliputi sapinda dan bukan sapinda, maka yang berhak mewaris berturutturut menurut golongannya adalah:

40 Baghavan Bhrgu, Manava Dharmasastra, 484.

41 Ibid., 466-467.

42 Kautilya (Canakya), Artasastra, 240.

43 Baghavan Bhrgu, Manava Dharmasastra, 466-468.

44 Ibid., 473-474.

45 Ibid.,469-471. 
a. Anak sendiri yang sah (putra aurasa), putra ksetraja46 dan anak angkat untuk pengganti status putra aurasa;

b. Anak angkat perempuan untuk status laki, anak-anak lainnya yang tidak berstatus aurasa, 47 yang terdiri dari anak rahasia48 dan anak buangan;49

c. Janda; d. Anak-anak perempuan yang belum menikah; e. Ayah dan Ibu;

f. Saudara/putra-putra saudara; g. Datuk dan nenek; h. Semua yang dekat dengan sapinda;

i. Keluarga; j. Guru/Murid; k. Raja/Brahmana di urutan terakhir. (Sloka 188 dan 189 Kitab Manava Dharmasastra).50

2. Dalam kitab Artasastra

Urutan pewarisan ahli waris juga tertuang dalam kitab Artasastra, yaitu pada sloka 10-13, 28, 29 dan sloka 15 Bagian 60 Bab 5 serta sloka 23 Bagian 60 Bab 6 Kitab Artasastra (yang juga telah disebutkan sebelumnya). Adapun bunyi Sloka 15 yang dimaksud yaitu:

Adapun antara ayah, kakak pria dan putera, selama yang pertama masih hidup, mereka tidak tergantung pada yang terakhir dan selama yang tertua masih hidup, mereka tidak tergantung pada yang terakhir dan selama yang tertua masih hidup, tergantung pada yang termuda, sekalipun ia menerima kekayaan.

Dari sloka-sloka yang telah disebutkan tersebut dapat disimpulkan bahwa golongan ahli waris mewarisi tidak secara bersama-sama tetapi secara bergantian dengan urutan sebagai

46 Putra yang dilahirkan dari perkawinan dengan janda saudara yang dulunya adik ipar atau anak hasil dari perkawinan niyoga, yaitu mengawini istri orang yang impoten, karena sakit walaupun suami pertama masih hidup dan hal ini dibenarkan oleh agama Hindu.

47 Baghavan Bhrgu, Manava Dharmasastra, 479-481.

48 Anak yang lahir tanpa kesaksian keluarga pada perkawinan, sedangkan perkawinan itu sendiri disahkan menurut agama.

49 Anak yang karena ketentuan agama sebagai akibat salah dibuang dari keluarga (Ibid., 477-478).

50 Ibid., 485 
berikut: 1) Anak; 2) Ayah; 3) Saudara laki-laki dan anak saudara laki-laki; 4) Guru/murid; dan 5) Raja/Brahmana.51

Adapun sebelum harta dibagikan kepada ahli waris, hutanghutang pewaris harus terlebih dahulu dilunasi.52 Dalam pembagian warisnya sendiri, disyaratkan adanya kehadiran para saksi. Apabila seseorang telah selesai membagi warisan dan ternyata warisan tersebut salah cara pembagianya, baik masih ada yang tersembunyi atau tidak ketahui, maka dapat dilakukan pembagian ulang. 53

\section{Kedudukan Anak Angkat Perspektif Hukum Islam dan Hindu}

Dari penjabaran di atas dapat, diketahui sebab-sebab seseorang mendapatkan warisan (menjadi ahli waris), baik menurut hukum Islam maupun Hindu. Adapun menurut Islam seseorang dapat menjadi ahli waris disebabkan oleh beberapa hal, yaitu karena kerabat hakiki (ikatan nasab), pernikahan, al-wala' (memerdekaan budak) dan representasi Islam (muslim), sedangkan menurut hukum Hindu, penyebabnya yaitu karena hubungan kekeluargaan, pengangkatan status anak perempuan menjadi anak laki-laki (putrika), pengangkatan anak (adopsi), hubungan guru dan murid, berkedudukan sebagai raja/brabmana.

Selain itu, diketahui pula bahwa ahli waris dalam Islam digolongkan menjadi ashab al-furud (para ahli waris yang mempunyai bagian tertentu yang telah ditetapkan oleh syara' (alQur'an), yaitu 2/3,1/3.1/6,1/2,1/4 dan 1/8), asabab (ahli waris yang tidak mempunyai bagian tertentu, tetapi menerima sisa pembagian setelah diambil oleh golongan ashab al-furud) dan dhawi al-arbam (setiap kerabat yang tidak termasuk ashab al-furud dan juga golongan 'asabab) dengan pewarisan yang tidak secara bersamaan tetapi secara bergantian, yaitu dengan cara mendahulukan ashab alfurud, kemudian 'asabah dan dhawi al-arham pada urutan terakhir.

Adapun dalam dalam hukum Hindu, ahli waris digolongkan menjadi sapinda (keluarga yang mempunyai hubungan darah ke atas tiga tingkat dan ke bawah tiga tingkat), anantara sapinda (keluarga-

51 Kautilya (Canakya), Artasastra, 237-238.

52 Baghavan Bhrgu, Manava Dharmasastra, 492.

53 Kautilya (Canakya), Artasastra, 238. 
keluarga lain dalam hubungannya dengan sapinda tersebut) dan sakulya (anggota keluarga dalam satu keluarga yang dekat hubungannya dan ini tidak perlu sedarah) dengan pewarisannya juga secara bergantian, yaitu dimulai dari golongan sapinda, kemudian anantara sapinda dan sakulya pada urutan terakhir.

Berdasarkan perbandingan di atas, khususnya mengenai sebab-sebab mendapatkan warisan/menjadi ahli waris dapat diketahui bahwa terdapat perbedaan antara kedua hukum tersebut dalam hal memposisikan pengangkatan anak angkat. Dari beberapa sebab yang dipaparkan, pengangkatan anak merupakan salah satu penyebab seseorang dapat menjadi ahli waris dalam Hukum Hindu dan ini tidak berlaku dalam hukum Islam karena pengangkatan anak bukan termasuk penyebab mendapatkan warisan dalam hukum Islam.

Pengangkatan anak (adopsi) sudah dikenal sejak zaman jahiliyyah, yang mana status anak angkat layaknya anak kandung dalam segala urusan, termasuk dalam hal nashab, warisan, mahram dan lainnya. Menurut sejarah, sebelum menjadi rasul, nabi Muhammad, saw. pernah mengadopsi Zaid bin Haritsah bin Syahril al-Kalbi, sehingga para sahabat biasa memanggilnya Zaid bin Muhammad. Akan tetapi, kemudian Allah membatalkan tradisi tersebut dengan menurunkan firman-Nya surat al-Ahzab ayat: 4-5 yang artinya:

Allah tidak menjadikan bagi seseorang dua bati dalam rongganya; dan Dia tidak menjadikan istri-istrimu yang kamu zihar itu sebagai ibumu, dan Dia tidak menjadikan anak angkatmu sebagai anak. kandungmu (sendiri). Yang demikian itu, hanyalah perkataan di mulutmu saja. Allah mengatakan yang sebenarnya dan Dia menunjukkan jalan (yang benar). Panggillah mereka (anak-anak angkat itu) dengan (memakai) nama bapak-bapak mereka; itulab yang adil di sisi Allah, dan jika kamu tidak mengetahui bapake mereka, maka (panggillah mereka sebagai) saudara-saudaramu seagama dan maula-maulamu. Dan tidak ada dosa atasmu jika kamu kbilaf tentang itu, tetapi (yang ada dosanya) apa yang disengaja oleh hatimu. Dan adalah Allah Maha Pengampun, Maha Penyayang. 
Ayat di atas juga dikuatkan oleh sabda Nabi Muhammad saw. yang artinya:

Barang siapa yang disebut bukan kepada bapaknya atau berafiliasi bukan kepada walinya, maka baginya laknat Allab yang berkelanjutan. (H.R. Abu Daud)

Salah satu akibat dari adanya ayat dan hadis di atas adalah dibatalkannya tradisi pewarisan yang terjadi antara ayah angkat dan anak angkatya yang tidak mempunyai hubungan sama sekali, dalam arti hak mewarisinya kembali ke keluarga kandungnya. Akan tetapi, dengan kewajiban berbuat baik antara keduanya, dalam hal ini ayah angkat diperbolehkan berwasiat kepada anak angkatnya dengan catatan tidak lebih dari $1 / 3$ bagian dari harta warisannya. Hal ini sesuai dengan firman Allah surat al-Ahzab ayat 6 yang artinya:

Nabi itu lebih utama bagi orang-orang mukmin dibandingkan diri mereka sendiri dan istri-istrinya adalab ibu mereka. Orang-orang yang mempunyai bubungan darah satu sama lain lebih berbak (warismewarisi) di dalam Kitab Allah daripada orang-orang mukmin dan Mubajirin, kecuali kalau kamu berbuat baik kepada saudarasaudaramu (seagama). Demikianlah telah tertulis dalam Kitab Allah.54

Dalam hal ini, bahkan Kompilasi Hukum Islam (KHI) menetapkan bahwa antara anak angkat dan orang tua angkatnya terbina hubungan saling berwasiat. Hal ini termuat dalam pasal 209 ayat 1 dan 2 KHI yang bunyinya:

(1) Harta anak angkat dibagi berdasarkan pasal 176 sampai dengan 193 tersebut di atas, sedangkan terhadap orang tua angkat yang tidak menerima wasiat diberi wasiat wajibah sebanyak-banyaknya $1 / 3$ dari harta warisan anak angkatnya.

(2) Terhadap anak angkat yang tidak menerima wasiat diberi wasiat wajibah sebanyak-banyaknya $1 / 3$ dari harta warisan orang tua angkatnya. 55

54 Departemen Agama RI, Al-Hidayah; Al-Qur'an Tafsir Per Kata Tajwid Kode Angka (Tanggerang Selatan: Kalim, t.t.), 419.

55 Pasal 209 ayat 1 dan 2 Kompilasi Hukum Islam. 
Berdasarkan pasal di atas, dapat diketahui bahwa orang tua angkat memiliki hak sebanyak-banyaknya $1 / 3$ dari harta warisan anak angkatnya berupa wasiat wajibah. Hal ini berlaku pula sebaliknya, dalam arti anak angkat juga memiliki hak sebanyakbanyaknya $1 / 3$ dari harta warisan orang tua angkatnya berupa wasiat wajibah

Berbeda dengan hukum Islam, dalam hukum Hindu, di samping mempunyai anak kandung, seseorang dapat melakukan adopsi (pengangkatan anak laki-laki) dengan ketentuan anak angkat tersebut tidak boleh memakai nama keluarga asalnya dan hak mewarisnya hapus dari keluarga asalnya dan berpindah ke keluarga angkatnya, sebagaimana disebut dalam sloka 142 dan 141 Buku IX Kitab Manava Dharmasastra yang berbunyi:

Anak angkat tidak pernah akan mengambil nama keluarga dan harta warisan dari orang tua yang sebenarnya, tarpana mengikuti nama keluarga dan harta warisan pemberian tarpana kepadanya yang memberikan anaknya untuk diadopsi berakhir sepanjang mengenai anak itu saja. (Sloka 142)

Jika orang laki-laki yang mempunyai anak angkat laki-laki yang memiliki sifat mulia, anak yang sama akan mewaris walaupun lahir dari keluarga lain. (Sloka 141)56

Dalam hal ini, kedudukannya sama dengan putera sah (putera yang diperoleh seseorang dengan isteri yang dikawini dengan baik). Hal ini sesuai dengan sloka 15 Bagian 60 Bab 7 Buku 3 Kitab Artasastra yang berbunyi:

Dengan hak sama adalah anak angkat, yang diberi bersama air oleh orang tuanya.57Adapun bagian anak angkat tersebut sebagai berikut:

1. Seluruh bagian jika tidak ada anak sama sekali, dengan dasar sloka 190 Buku IX Kitab Manava Dharmasastra yang berbunyi:

56 Baghavan Bhrgu, Manava Dharmasastra, 473.

57 Kautilya (Canakya), Artasastra, 243. 
Jika janda seorang yang mati tanpa turunan, telah mengangkat anak yang sekeluarga, ia harus menyerahkan seluruh harta milik meninggal kepada anak itu. 58

2. Sama dengan bagian anak sah, dalam arti mewaris bersama

Akan tetapi, penafsiran berhak mewarisi bersama tersebut tidak diakui sepenuhnya karena di antara penulis, seperti Bhagawan Nanda mengartikan bagian terakhir dari sloka 141 dengan berhaknya mewarisi anak angkat tersebut, bila ayah angkatnya tidak punya anak laki-laki dan penafsiran ini tidak bertentangan dengan sistem angkat sentana, yaitu bentuk perkawinan di mana menantu laki-laki itu berhak mewaris bersama istrinya (putrika).59 Adapun jika disamakan, maka anak angkat (laki-laki) akan mewarisi pada urutan pertama bersama anak lainnya (putra aurasa dan ksetraja) karena urutan pewarisan ketiga golongan ahli waris (sapinda, anantara sapinda dan sakulya) tersebut adalah secara bergantian sebagai berikut:

1. Anak sendiri yang sah (putra aurasa), putra ksetraja dan anak angkat untuk pengganti status putra aurasa;

2. Anak angkat perempuan untuk status laki, anak-anak lainnya yang tidak berstatus aurasa, yang terdiri dari anak rahasia dan anak buangan;

3. Janda; 4. Anak-anak perempuan yang belum menikah; 5 . Ayah dan Ibu.

6. Saudara/putra-putra saudara; 7. Datuk dan nenek; 8. Semua yang dekat dengan sapinda.

9. Keluarga; 10. Guru/ Murid; k. Raja/brahmana di urutan terakhir. (Sloka 188 dan 189 Buku Kitab Manava Dharmasastra).60

Urutan pewarisan ahli waris juga tertuang dalam kitab Artasastra, yaitu pada sloka 10-13, 28, 29 dan sloka 15 Bagian 60 Bab 5 serta sloka 23 Bagian 60 Bab 6 Kitab Artasastra (yang telah disebutkan sebelumnya) dapat disimpulkan bahwa

58 Baghavan Bhrgu, Manava Dharmasastra, 467-468.

59 Ibid., 473-474.

60 Ibid., 485 
golongan ahli waris mewarisi tidak secara bersama-sama tetapi secara bergantian dengan urutan sebagai berikut: 1) Anak; 2) Ayah; 3) Saudara laki-laki dan anak saudara laki-laki; 4) Guru/murid; dan 5) Raja/Brahmana di urutan terakhir.61

\section{Penutup}

Baik hukum Islam maupun hukum Hindu telah mengatur secara rinci berbagai persoalan mengenai kewarisan, yang di antaranya meliputi sebab-sebab mendapatkan warisan, penggolongan ahli waris dan bagiannya masing-masing beserta tata cara pembagian hartanya. Jika dibandingkan, khususnya mengenai sebab-sebab mendapatkan warisan, dapat diketahui bahwa terdapat perbedaan antara kedua hukum tersebut dalam memposisikan pengangkatan angkat, yang mana dalam hukum Hindu dijadikan sebagai penyebab mendapatkan harta warisan sedangakan dalam hukum Islam tidak.

Dengan demikian, dapat diketahui bahwa anak angkat tidak termasuk golongan ahli waris dalam Hukum Islam sehingga hak mewarisinya tetap ke keluarga kandungnya, bukan keluarga angkatnya. Akan tetapi, bisa mendapat bagian dari harta orang tua angkatnya dengan jalan wasiat yang tidak lebih dari $1 / 3$ bagian harta warisan, bahkan dalam hal ini, pasal 209 ayat 2 menyatakan bahwa terhadap anak angkat yang tidak menerima wasiat diberi wasiat wajibah sebanyak-banyaknya $1 / 3$ dari harta warisan orang tua angkatnya. Berbeda halnya dengan Hukum Islam, Hukum Hindu menggolongkan anak angkat (laki-laki) termasuk ke dalam ahli waris yang hak mewarisinya berpindah ke keluarga angkatnya dan kedudukannya sama dengan anak sah yang mewarisi pada urutan pertama dengan kemungkinan bagiannya adalah seluruh bagian jika tidak ada anak sama sekali atau sama dengan bagian anak sah, dalam arti mewaris bersama.

\section{Daftar Pustaka}

Abdur Rahman I. Doi. Syariah II; Hudud dan Kewarisa, terj. Zaimuddin, et al. Jakarta: PT Raja Grafindo Persada, 1996.

61 Kautilya (Canakya), Artasastra, 237-238. 
Abu 'Abdillah Muhammad ibn Yazid Quzwaini (al), Sunan Ibn Majah, juz VIII. t.tp.: t.p., t.t..

Ahmad 'Abd Jawad (al). Usul; Ilm al-Mawaris. Beirut: Dar al-Ji, 1986.

Amir Syarifuddin. Hukum Kewarisan Islam. Jakarta: Kencana, 2004.

Azyumardi Azra. "Waris", Ensiklopedi Islam, vol. 5, ed. Abdul Aziz

Dahlan, et al. Jakarta: PT Ikrar Mandiri Abadi, 2000.

Baghavan Bhrgu. Manava Dharmasastra, terj. G. Pudja dan Tjokorda

Rai Sudharta. Surabaya: Paramita, 2004.

Fatchur Rahman. Ilmu Waris. Bandung: Al-Ma'arif, 1974.

Imam Abi Abdillah Muhammad ibn Isma'il ibn Ibrahim ibn al-

Mughirah ibn Bardazabah al-Bukhari Ja'fiyyi (al), Sabih al-

Bukhari, juz VIII. Beirut: Dar al-Fikr, 2000.

Kautilya (Canakya). Artasastra, terj. Made Astana dan Anomdiputro. Surabaya: Paramita, 2003.

M. Ali Shabuni (ash). Pembagian Waris Menurut Islam, terj. A.M.

Basalamah. Jakarta: Gema Insani Press, 1995.

Moh. Muhibbin. dan Abdul Wahid. Hukum Kewarisan Islam; Sebagai

Pembaharuan Hukum Positif di Indonesia. Jakarta: Sinar Grafika, 2009.

Muhammad ibn Isma'il ibn 'Abdullah Ja'fiy (al), Sabih al-Bukhari. Beirut: Dar al-Fikr, 1987), 6.

Sayyid Sabiq Fikih Sunnah, 14, terj. Mudzakir. Bandung: PT Alma'arif, 1987.

Suhrawardi K Lubis dan Komis Simanjuntak, Hukum Waris Islam; Lengkap \& Praktik. Jakarta: Sinar Grafika, 2008.

Suparman Usman dan Yusuf Somawinata, Fiqih Mawaris; Hukum Kewarisan Islam. Jakarta: Gaya Media Pratama, 2002.

Wahbah Zuhaily (al). Fiqih Islam wa Adillatuhu, 10, terj. Abdul Hayyie al-Kattani, et al. Jakarta: Gema Insani, 2011.

Departemen Agama, Al-Quran dan Terjemahnya. Bandung: Diponegoro, 2010.

Departemen Agama RI. Al-Hidayab; Al-Qur'an Tafsir Per Kata Tajwid Kode Angka. Tanggerang Selatan: Kalim, t.t.

Hukum Hindu. "Hukum Waris Hindu Berdasarkan Arthasastra", dalam http://hukumhindu.blog.com/2011/06/25/hukum- 
Zakiyatul Ulya: Kedudukan Anak Angkat dalam Hukum...

waris-hindu-berdasarkan-arthasastra/, diakses pada 7 Desember 2013.

Kompilasi Hukum Islam. 